\title{
Hydrogen peroxide bleaching of cellulose pulps obtained from brewer's spent grain
}

\author{
Solange I. Mussatto • George J. M. Rocha • \\ Inês C. Roberto
}

Received: 9 October 2007 / Accepted: 2 January 2008/Published online: 19 January 2008

(C) Springer Science+Business Media B.V. 2008

\begin{abstract}
Brewer's spent grain (BSG) was evaluated for bleached pulp production. Two cellulose pulps with different chemical compositions were produced by soda pulping: one from the original raw material and the other from material pretreated by dilute acid. Both of them were bleached by a totally chlorine-free sequence performed in three stages, using 5\% hydrogen peroxide in the two initial, and a $0.25 \mathrm{~N} \mathrm{NaOH}$ solution in the last one. Chemical composition, kappa number, viscosity, brightness and yield of bleached and unbleached pulps were evaluated. The high hemicellulose $(28.4 \% \mathrm{w} / \mathrm{w})$ and extractives $(5.8 \% \mathrm{w} / \mathrm{w})$ contents in original BSG affected the pulping and bleaching processes. However, soda pulping of acid pretreated BSG gave a celluloserich pulp $(90.4 \% \mathrm{w} / \mathrm{w})$ with low hemicellulose and extractives contents $(7.9 \% \mathrm{w} / \mathrm{w}$ and $<3.4 \% \mathrm{w} / \mathrm{w}$, respectively), which was easily bleached achieving a kappa number of 11.21, viscosity of $3.12 \mathrm{cp}$, brightness of $71.3 \%$, cellulose content of $95.7 \% \mathrm{w} / \mathrm{w}$, and residual lignin of $3.4 \% \mathrm{w} / \mathrm{w}$. Alkaline and oxidative delignification of acid pretreated BSG was found as an attractive
\end{abstract}

S. I. Mussatto - G. J. M. Rocha - I. C. Roberto

Departamento de Biotecnologia, Escola de Engenharia de Lorena, Universidade de São Paulo, Lorena, SP, Brazil

S. I. Mussatto $(\square)$

Departamento de Engenharia Biológica, Universidade do Minho, Campus de Gualtar, 4710-057 Braga, Portugal e-mail: solange@deb.uminho.pt;

solangemussatto@hotmail.com approach for producing high-purity, chlorine-free cellulose pulp.

Keywords Bleaching - Brewer's spent grain · Cellulose $\cdot$ Hydrogen peroxide $\cdot$ Pulp

\section{Introduction}

The paper consumption in the world has increased by $50 \%$ during the last decade, and the quantitative growth of paper production has been accompanied by a demand for new grades and by technological developments in response to ecological challenges (López et al. 2001, 2003). In this sense, because of the overproduction of agricultural crops and the shortage of wood, non-woody materials such as annual plants and agricultural residues have received more attention in recent years for producing pulp, paper, paperboard, and cellulose derivatives. Actually, non-woody is gradually substituting wood for paper and paperboard production for economic and environmental considerations (Ye et al. 2005).

Brewer's spent grain (BSG) is an agro-industrial by-product from breweries, available at low ( US\$ 14/ton wet BSG) or no cost throughout the year, and produced in large quantities not only by large, but also small breweries (Mussatto et al. 2006a). For example Brazil, the world's fifth largest beer producer, $\sim 9.7$ billion liters/year, in 2006 generated around 2 million tonnes of spent grain. Although the large 
availability of this material throughout the year, its main application has been limited to animal feeding. Recently, BSG shown to be a potential alternative source for pulp and paper production (Mussatto et al. 2006b), but there is not any investigation on the bleachability of pulps from this raw material.

Historically, pulp and paper production has been recognized as a significant source of pollution, since large amounts of solid residues, toxic effluents and gases are generated from the different steps of the pulping and bleaching processes. For example, pulping black liquors contain high amounts of phenolic compounds, which have a powerful toxic effect on microorganisms even at low concentrations (Mishra et al. 1995; Fortuny et al. 1998); and the pulps bleached with chlorinated chemicals (chlorine and chlorine dioxide) produce chlorolignins highly resistant to biodegradation, as well as other polluting compounds that could be acutely toxic, mutagenic and carcinogenic (Rahmawati et al. 2005). Although the chlorine and its derivatives are effective and cheap bleaching agents (Bianchi et al. 1999), environmental concerns have created a need for new technologies using other non-polluting bleaching sequences for pulp, based on the use of elemental chlorine-free or totally chlorine-free procedures (Rahmawati et al. 2005; Tanaka et al. 2004; Tutus 2004).

Totally chlorine-free pulp bleaching using oxygencontaining oxidative chemicals (such as molecular oxygen, ozone and hydrogen peroxide) has proved to be among the best potential alternatives to conventional chlorine-based industrial pulping and bleaching technologies both with respect to environment and economy (Shatalov and Pereira 2007; Weinstock et al. 1996). Among these chemicals, hydrogen peroxide is recognized as an environmentally friendly and strong oxidizing agent, being considered as one of the most important bleaching chemicals. In alkaline media, the equilibrium of $\mathrm{H}_{2} \mathrm{O}_{2}$ shifts to the formation of hydroperoxide anion $(-\mathrm{OOH})$ that is the principal active species in peroxide bleaching (Rahmawati et al. 2005; Brooks and Moore 2000). This anion is a strong nucleophile which, during bleaching, converts electron-rich chromophores typified by unsaturated aldehydes and ketones, and phenolic ring-conjugated ethylenic or carbonyl groups to their non-chromophoric counterparts. The reactions of lignin with peroxide are not reversible and lead to the permanent removal of most of the chromophoric groups present in the lignin molecule (Rahmawati et al. 2005; Tutus 2004).

The present study evaluated the possibility of producing high-purity bleached cellulose pulp from BSG, using an environmentally friendly procedure free of chlorine. This is a first approach on the bleaching of cellulose pulps obtained from BSG. Two pulps with different chemical composition were obtained, one from the original raw material, and the other from the material pretreated by dilute acid. Both of them were bleached by a totally chlorine-free sequence performed in three stages, using hydrogen peroxide in the two initial, and a sodium hydroxide solution in the last one. The chemical composition, kappa number, viscosity, brightness, and yield of the resulting bleached pulps were evaluated in order to determine the quality of them and the efficiency of the bleaching process.

\section{Material and methods}

\section{Raw material preparation}

The BSG used in the experiments was supplied by the microbrewery of the Engineering College of Lorena. As soon as obtained, the material was washed with water to remove the wort residues, and dried at $50 \pm 5{ }^{\circ} \mathrm{C}$ to $10 \%$ moisture content. This was termed as original BSG. An original BSG sample was pretreated with $1.25 \%(\mathrm{w} / \mathrm{v})$ sulfuric acid solution under the conditions defined by Mussatto and Roberto (2005): solid:liquid ratio of 1:8 g:g, $120{ }^{\circ} \mathrm{C}, 17 \mathrm{~min}$. After the reaction, the solid residue was separated by centrifugation, washed with water until neutral $\mathrm{pH}$ and dried at $50 \pm 5{ }^{\circ} \mathrm{C}$ to $10 \%$ moisture content. This was termed as acid pretreated BSG.

Soda pulping procedure

Unbleached pulps were obtained from both, original and acid pretreated BSG. For soda pulping reaction, 500-mL stainless steel batch cylindrical reactors were filled with the BSG and a $2 \%(\mathrm{w} / \mathrm{v})$ soda solution in a solid:liquid ratio of 1:20 g:g. In the sequence, the reactors were introduced into a silicone oil bath at $120{ }^{\circ} \mathrm{C}$ and maintained during $90 \mathrm{~min}$, 
being subsequently cooled in ice bath. The pulps were thus separated from the black liquors by filtration in $100 \%$ polyester cloth, exhaustively washed with distilled water to remove residual alkali, dried at $50 \pm 5{ }^{\circ} \mathrm{C}$ to $10 \%$ moisture content, and screened to separate shives. The pulp obtained from original raw material was termed as original BSG pulp, while that obtained from acid pretreated material was termed as pretreated BSG pulp.

Pulp bleaching procedure

BSG pulps free of shives were submitted to an oxidative delignification process using hydrogen peroxide. This bleaching process was done in three stages, using hydrogen peroxide during the two initial, and only a sodium hydroxide solution in the last one. Initially, pulp slurry of $10 \%$ consistency (adjusted using $0.07 \mathrm{~N} \mathrm{NaOH}$ aqueous solution) was mixed with the corresponding amount of $5 \% \mathrm{H}_{2} \mathrm{O}_{2}$ and stirred at $70{ }^{\circ} \mathrm{C}$ for $40 \mathrm{~min}$. The $\mathrm{pH}$ of bleaching solution was $12-12.5$, but at the reaction end it was reduced to approximately 11 . Thus, the pulp was filtered in a Buckner funnel, extensively washed with distilled water, and dried at room temperature for $24 \mathrm{~h}$. This procedure was performed for two consecutive times. In the third and last bleaching stage, the pulp was mixed with a $0.25 \mathrm{~N} \mathrm{NaOH}$ aqueous solution in a consistency of $10 \%$, and stirred at $70{ }^{\circ} \mathrm{C}$ for $60 \mathrm{~min}$. Subsequently, the bleached pulp was washed with excess distilled water to remove the residual alkali and dried at room temperature until approximately $10 \%$ moisture content.

\section{Characterization of BSG pulps}

The carbohydrate, lignin and ashes contents of the pulps were estimated by following standard procedures (Browning 1967). Pulp yield expressed in screened material basis (referred to dry matter) was determined gravimetrically and the moisture content was estimated by drying to constant weight. The kappa number and viscosity were determined by following Tappi standard methods T $236 \mathrm{~cm}-85$ and T 230 om-94, respectively. Sheets of paper with $7.5 \mathrm{~cm}$ of diameter were made from the different pulps (basis weight $\approx 90 \mathrm{~g} / \mathrm{m}^{2}$ ) and used for measuring brightness, according to Tappi 452 om98 method. The reflectance at $457 \mathrm{~nm}$ of the surface was estimated by placing each sheet directly over the measurement compartment of a Photovolt-577 apparatus. Micrographs of BSG pulps were obtained by scanning electron microscopy (SEM) using a LEO microscope model 1450VP. All the assays and analysis were performed in duplicate, and the results are expressed as means values.

\section{Results and discussion}

Chemical composition of the pulps

A principal goal in conversion of lignocellulosics to high quality paper products is to selectively remove lignin and hemicellulose without damaging the cellulose structure. Lignin affects the paper manufacture and decreases the pulp brightness level, so, it must be removed as much possible (Grace et al. 1996; Chen et al. 2001). Only minute quantities of residual materials derived from lignin remain in the paper after pulping and bleaching processes (Weinstock et al. 1996). On the other hand, hemicellulose has contradictory effects on the quality of the sheets made from pulp. High amounts of hemicellulose are deleterious to the mechanical properties of the paper due to a decrease in the individual fiber resistance and to the optical properties due to the low opacity in the paper sheet. However, the presence of low hemicellulose contents in the cellulosic pulp improve some features of papermaking, such as: (1) The time and energy utilized to achieve a required fibrillation level can be diminished during the refining process, (2) The plasticity and the high superficial area conferred by hemicelluloses result in an increased binding among the fibers and a higher tensile strength in the paper sheet (D'Almeida 1988; Lima et al. 2003).

The composition results based on dried weight of the original and acid pretreated BSG are listed in Table 1 . Note that original BSG is characterized by its high hemicellulose and lignin contents $(\approx 28 \%$ w/w), which are almost 2-fold higher than that of cellulose. Acid pretreatment of the material removed a significant amount $(>83 \% \mathrm{w} / \mathrm{w})$ of hemicellulose and also the fraction corresponding to ashes, protein and extractives (Table 2). As a consequence, the resulting solid material (pretreated BSG) was 
Table 1 Chemical composition of BSG in the original (OBSG) and acid pretreated (P-BSG) forms

\begin{tabular}{lrr}
\hline Component & \multicolumn{2}{l}{ Composition (\% dry weight) } \\
\cline { 2 - 3 } & \multicolumn{1}{l}{ O-BSG } & \multicolumn{1}{c}{ P-BSG } \\
\hline Cellulose & $16.8 \pm 0.8$ & $34.0 \pm 2.2$ \\
Hemicellulose & $28.4 \pm 2.0$ & $7.9 \pm 0.5$ \\
Lignin & $27.8 \pm 0.3$ & $49.2 \pm 1.6$ \\
Ashes & $4.6 \pm 0.2$ & $5.5 \pm 0.4$ \\
Others $^{\mathrm{a}}$ & $22.4 \pm 1.2$ & $3.4 \pm 0.2$ \\
\hline
\end{tabular}

${ }^{\text {a }}$ Other components include protein and extractives

enriched in cellulose and lignin (Table 1). Hemicellulose is really more susceptible to attack with dilute acids than cellulose or lignin (Grace et al. 1996; McMillan 1994). This probably occurs because its structure is ramified and the sugar units are linked by bonds weaker than those of the glucose units in cellulose. Lignin is a cross-linked hydroxylated and methoxylated aromatic macromolecule that gives color, resistance to biological attack and structural rigidity to the material cell wall, and because its different units are linked by series of ether and carbon-carbon linkages, it presents considerable resistance to chemical degradation (Weinstock et al. 1996; Chen et al. 2001).

The different materials (original and pretreated BSG) were subjected to the same pulping process, but pulps of different characteristics were obtained. Original BSG (O-BSG) pulping promoted high hemicellulose and lignin removal $(>78 \% \mathrm{w} / \mathrm{w})$ and practically did not interfere in the cellulose fraction that was removed in $3.0 \% \mathrm{w} / \mathrm{w}$ only (Table 2). As a consequence, the cellulose content in O-BSG was increased 3.2-fold, reaching $54.3 \% \mathrm{w} / \mathrm{w}$ of the material composition (Table 3). Similar increase in the cellulose content (2.7-fold) was achieved after pulping of the pretreated BSG (P-BSG), while was also due to the high hemicellulose and lignin removals $(>94 \% \mathrm{w} / \mathrm{w})$ and low cellulose removal ( $\cong 10 \% \mathrm{w} / \mathrm{w}$, Table 2). Nevertheless, since the pretreated material presented a cellulose content 2-fold higher than that of the original BSG (Table 1), their pulp also achieved a cellulose content $(90.4 \% \mathrm{w} / \mathrm{w})$ almost 2 -fold higher than that of the O-BSG pulp $(54.3 \% \mathrm{w} / \mathrm{w})$ (Table 3).

Other characteristics of both, O-BSG and P-BSG pulps, including the compositional data, yield, kappa number, viscosity and brightness, are shown in Table 3. Note that pulping yield was similar for both, O-BSG and P-BSG pulps $(30.1 \%$ and $33.5 \%$ $\mathrm{w} / \mathrm{w}$, respectively). However, since the pretreated material had been recovered with $48.6 \% \mathrm{w} / \mathrm{w}$ yield, the total pulp mass obtained from P-BSG was of only $16.3 \mathrm{~g}$ from each $100 \mathrm{~g}$ original BSG; while for O-BSG, $30.1 \mathrm{~g}$ of pulp were obtained. Similar pulp yield $(27.9 \%)$ was found after soda pulping of date palm leaves (Khristova et al. 2005). In this case, the authors attributed the low pulping yield to the low cellulose content $(30.3 \% \mathrm{w} / \mathrm{w})$, and the high lignin $(31.2 \% \mathrm{w} / \mathrm{w})$ and extractives $(21.2 \% \mathrm{w} / \mathrm{w})$ contents present in that raw material. Considering this fact, the low yields obtained for the BSG pulps are justifiable, since the cellulose content was low for P-BSG and mainly for O-BSG, while the lignin content was high for O-BSG and mainly for P-BSG (Table 1).

Table 2 Recovered mass (RM) and removal of each fraction (FR) after pulping and acid pretreatment of BSG

\begin{tabular}{|c|c|c|c|c|c|c|c|}
\hline & \multicolumn{2}{|c|}{ Original BSG after acid pretreatment } & \multicolumn{2}{|c|}{ Original BSG after soda pulping } & \multicolumn{3}{|c|}{ Pretreated BSG after soda pulping } \\
\hline & $\mathrm{RM}^{\mathrm{a}}(\mathrm{g})$ & $\mathrm{FR}(\% \mathrm{w} / \mathrm{w})$ & $\mathrm{RM}^{\mathrm{a}}(\mathrm{g})$ & $\mathrm{FR}(\% \mathrm{w} / \mathrm{w})$ & $\mathrm{RM}^{\mathrm{b}}(\mathrm{g})$ & $\mathrm{FR}^{\mathrm{c}}(\% \mathrm{w} / \mathrm{w})$ & $\mathrm{FR}^{\mathrm{d}}(\% \mathrm{w} / \mathrm{w})$ \\
\hline Cellulose & 16.5 & 1.8 & 16.3 & 3.0 & 14.7 & 10.9 & 12.5 \\
\hline Hemicellulose & 3.8 & 86.6 & 6.1 & 78.5 & 0.2 & 94.7 & 99.3 \\
\hline Lignin & 23.9 & 14.0 & 4.3 & 84.5 & 1.3 & 94.6 & 95.3 \\
\hline Others $^{\mathrm{e}}$ & 4.4 & 83.7 & 3.4 & 87.4 & 0.1 & 97.7 & 99.6 \\
\hline Total & 48.6 & 51.4 & 30.1 & 69.9 & 16.3 & 66.5 & 83.7 \\
\hline
\end{tabular}

${ }^{a}$ Value correspondent to the mass recovered from each $100 \mathrm{~g}$ of the original material

b Value correspondent to the mass recovered from each $48.6 \mathrm{~g}$ of the pretreated material

c Removal calculated from the pretreated material

d Total removal calculated from original material

e Other components include ashes, protein and extractives 
Table 3 Yield and characteristics of the cellulose pulps obtained by soda pulping of BSG in the original (O-BSG) and acid pretreated (P-BSG) forms ${ }^{\mathrm{a}}$

a The results are mean values of two replicates. For all the cases the standard deviation was correspondent to less than $10 \%$ of the real value obtained

b Calculated for each process individually

\begin{tabular}{|c|c|c|c|c|}
\hline \multirow[t]{2}{*}{ Characteristics } & \multicolumn{2}{|l|}{ O-BSG pulp } & \multicolumn{2}{|l|}{ P-BSG pulp } \\
\hline & Unbleached & Bleached & Unbleached & Bleached \\
\hline $\begin{array}{l}\text { Cellulose } \\
\qquad(\% \mathrm{w} / \mathrm{w})\end{array}$ & 54.3 & 60.8 & 90.4 & 95.7 \\
\hline $\begin{array}{l}\text { Hemicellulose } \\
(\% \mathrm{w} / \mathrm{w})\end{array}$ & 20.4 & 13.7 & 1.1 & 0 \\
\hline $\begin{array}{l}\text { Lignin } \\
\qquad(\% \mathrm{w} / \mathrm{w})\end{array}$ & 14.4 & 12.6 & 8.1 & 3.4 \\
\hline Ashes $(\% \mathrm{w} / \mathrm{w})$ & 3.1 & 1.4 & 0.4 & 0.3 \\
\hline Yield $^{\mathrm{b}}(\%)$ & 30.1 & 78.8 & 33.5 & 88.9 \\
\hline Kappa number & 48.4 & 40.2 & 27.9 & 11.2 \\
\hline Viscosity (cp) & 13.7 & 10.9 & 12.5 & 3.1 \\
\hline Brightness (\%) & 27.2 & 39.1 & 33.8 & 71.3 \\
\hline
\end{tabular}

Although the higher yield, O-BSG pulp was of worst quality than P-BSG pulp, due to its higher kappa number (48.4) and lower brightness (Table 3). Baudel et al. (2005) also produced a pulp with kappa number of 48.4 from soda/anthraquinone pulping of pretreated sugarcane bagasse. According to these authors, this high value of kappa number could be related to the presence of hemicellulose-derived carbohydrates in the pulp produced. In unbleached pulps, although lignin always seems to dominate the determination of kappa number, contributions from other carbohydrates are substantial (Gellerstedt 2001).

\section{Bleaching}

Bleached BSG pulps presented different properties according to the material used, demonstrating that the dilute acid pretreatment before pulping process affected the characteristics of the produced pulps. The kappa number, lignin content, and viscosity of bleached P-BSG pulp were lower than those of bleached O-BSG pulp, while the brightness and cellulose content were higher (Table 3 ).

The kappa number (an index of lignin content) of bleached P-BSG pulp was low ( $\cong 11.0)$, indicating that most of the lignin present in the unbleached pulp was removed using this chlorine-free sequence. On the other hand, bleached O-BSG pulp presented elevated kappa number ( $\cong 40.0$ - Table 3 ). Probably the presence of extractives in this material negatively affected the bleaching process. This fraction consist of resins, waxes, fats, gums, starches, tannins, essential oils, and various other cytoplasmatic constituents (Kuhad and Singh 1993) and according to Fengel and Wegener (1989) must be removed prior the lignin isolation to avoid the formation of condensation products with lignin during the pulping process. In fact, it was visually noted the formation of a gum after O-BSG pulping, which caused strong adhesion of the cellulose fibers to each other (Fig. 1b). Bleaching of this pulp was not successful since the cellulose fibers remained strongly adhered (Fig. 1c), and the bleached pulp had yellow color (Fig. 2c) due to the high lignin content $(12.6 \% \mathrm{w} / \mathrm{w})$ and the corresponding brightness was $39.1 \%$ (Table 3 ). These results are in agreement with the observations of Argyropoulos et al. (1999) who reported that condensation products with lignin formed during pulping process decreases the solubility of the residual lignin, interfering with the complete removal of this fraction, especially during the final stages of most pulping processes. The extractives have also been recently considered detrimental to mechanical properties of bleached pulps due to reduction of fiber-to-fiber bonding (Fardim and Durán 2005).

For P-BSG bleached pulp the results were better, probably due to the low extractives and hemicellulose contents in the pretreated material (Table 2). As a consequence of the acid pretreatment, a major disaggregating of the fibers occurred (Fig. 1d) and the material became more susceptible to the alkali attack. More efficient lignin degradation thus occurred releasing the cellulose fibers, as can be seen in Fig. 1e. In this case was not observed the formation of a gum as observed for O-BSG pulp, and the cellulose pulp was 
Fig. 1 Micrograph, by SEM, of BSG in the following forms: original (a), original BSG unbleached pulp (b), original BSG bleached pulp (c), acid pretreated (d), pretreated BSG unbleached pulp (e), and pretreated BSG bleached pulp (f). Magnification: 300-fold
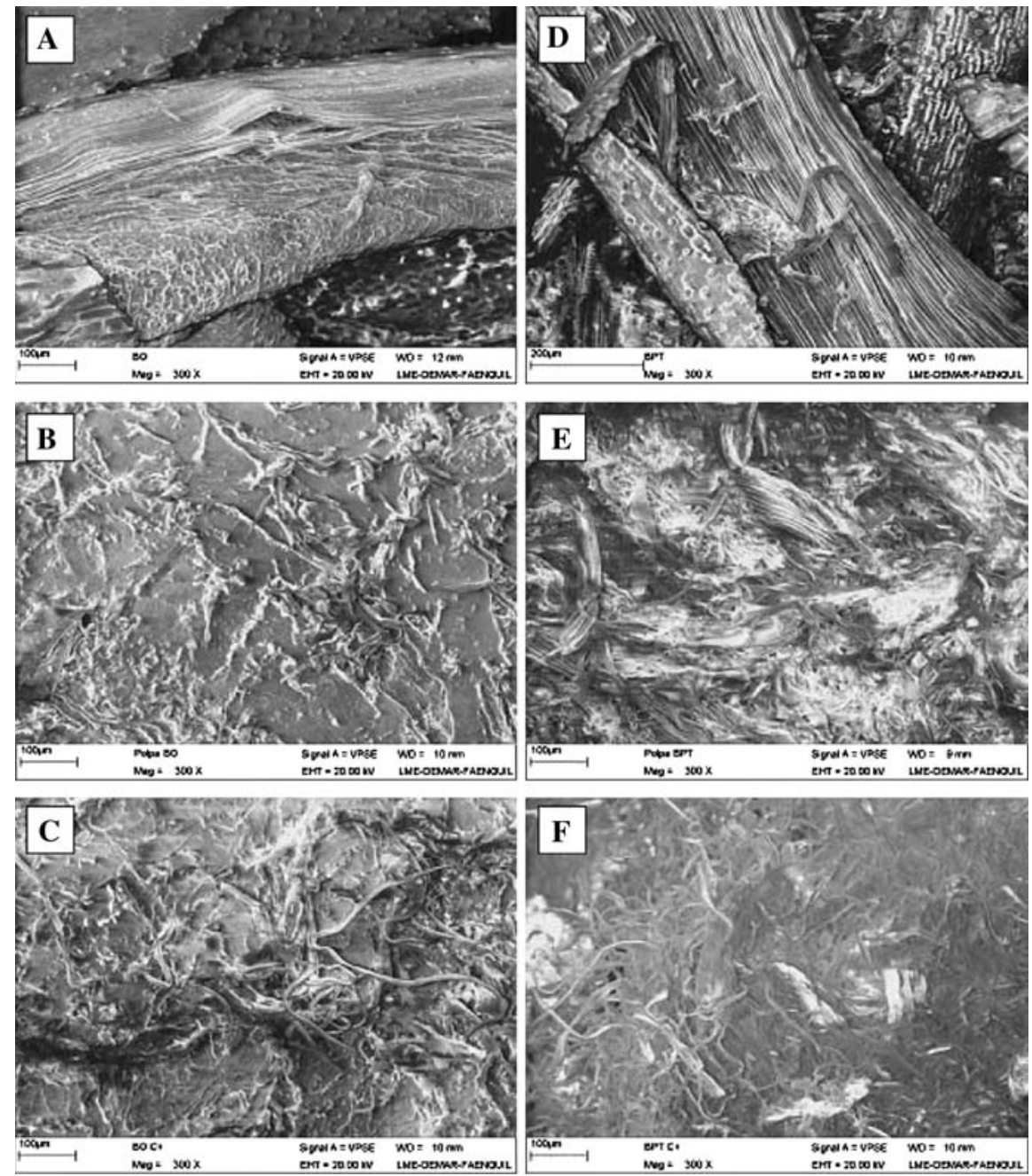

more easily bleached achieving a white color (Fig. 2f) correspondent to a brightness of $71.3 \%$.

A brightness of $71.3 \%$ is a good value considering the simplicity of the bleaching process employed and the use of a chlorine-free sequence. Tanaka et al. (2004) achieved 73-74\% brightness in a Kraft pulp produced from oil palm empty fruit bunches, after bleaching with a more arduous four steps sequence using $\mathrm{O}_{2}$, acid, $\mathrm{O}_{3}$ and $\mathrm{H}_{2} \mathrm{O}_{2}$. Tutus (2004) obtained a soda-oxygen-anthraquinone rice straw pulp with $68.34 \%$ brightness using a bleaching procedure of only one peroxide stage. In this case, the author used $3 \% \mathrm{H}_{2} \mathrm{O}_{2}$ in mixture with a $2.25 \% \mathrm{NaOH}$ solution. In the present work, the bleaching process was performed in three stages, but using less severe reaction conditions, based on the use of $5 \% \mathrm{H}_{2} \mathrm{O}_{2}$ in mixture with $0.28 \% \mathrm{NaOH}$ solution, a concentration value almost 10-fold lower. In addition, the bleached pulp obtained by Tutus (2004) presented a kappa number of 14.15, while in the present work, bleached P-BSG pulp had a lower kappa number (11.2), suggesting that a lesser amount of lignin remained in the bleached pulp although the reaction conditions used were less severe.

Viscosity of P-BSG pulp was strongly decreased after bleaching (from 12.5 to $3.1 \mathrm{cp}$ ), indicating that the average cellulose chain length (polymerization degree) was reduced, since viscosity loss occurs due to the random alkaline-catalyzed cleavage of glycosidic bonds in this polysaccharide chain $(\mathrm{Vu}$ et al. 2004). Although the goal of selective bleaching is to reduce the kappa number without causing a decrease in pulp viscosity (Weinstock et al. 1996), in most pulping and bleaching processes, is verified a decrease 
Fig. 2 Appearance of BSG in the following forms: original (a), original BSG unbleached pulp (b), original BSG bleached pulp (c), acid pretreated (d), pretreated BSG unbleached pulp (e), and pretreated BSG bleached pulp (f)
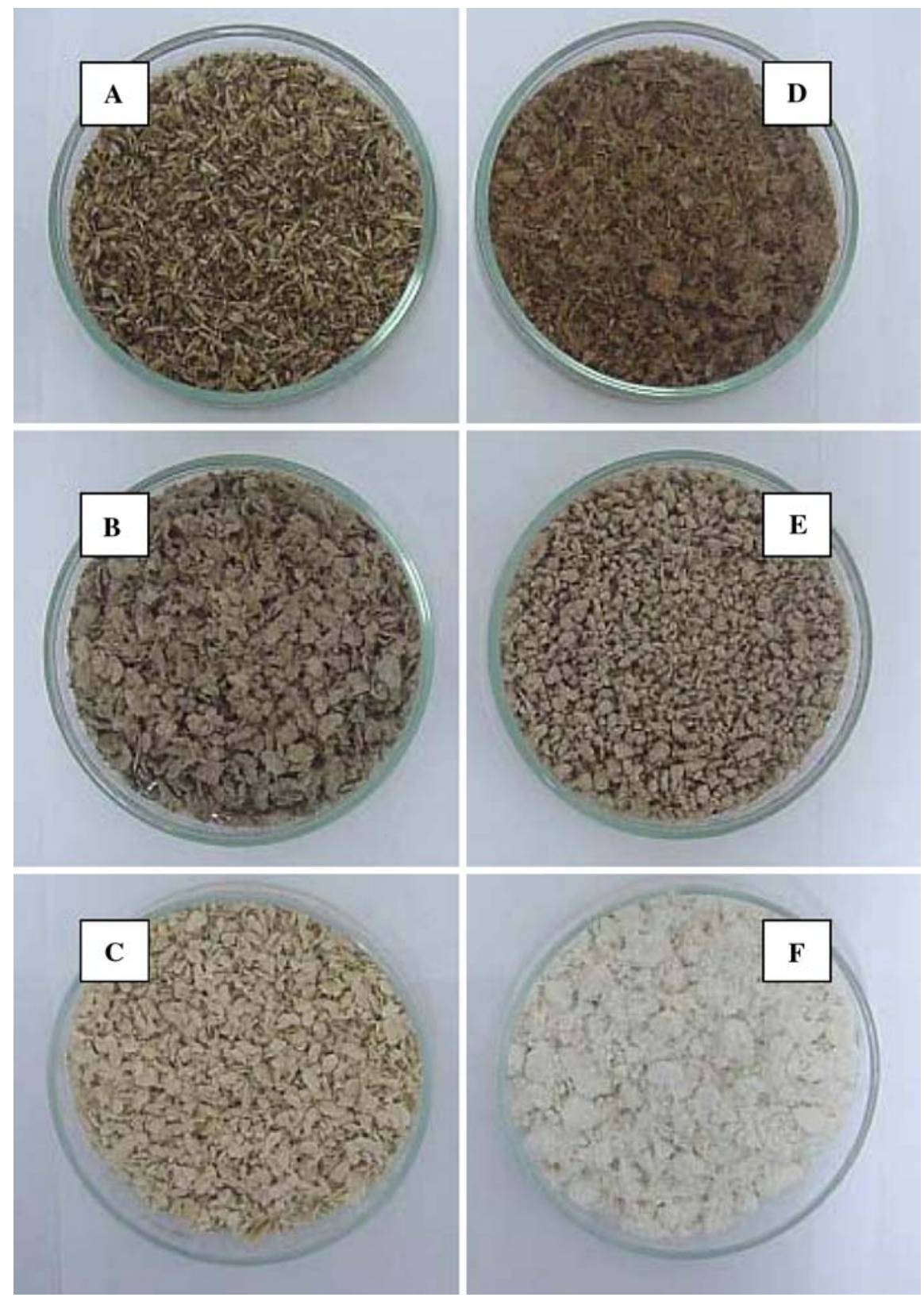

in the cellulose polymerization degree due to degradation by random hydrolysis (Zou et al. 2002). As a consequence, the pulp viscosity is also decreased. According to Abrantes et al. (2007), although hydrogen peroxide is a successful bleaching agent, its effectiveness is limited by a poor selectivity, which is reflected by a severe viscosity loss. It is generally admitted that the radicals generated during the peroxide decomposition are responsible for this cellulose degradation. A possible alternative to minimize this problem would be the use of magnesium sulfate in the peroxide stage, because this salt is reported as extremely efficient at reducing the rate of peroxide decomposition and thus it could prevent the radical degradation reactions of carbohydrates (Lapierre et al. 2003).

During the O-BSG pulp bleaching viscosity loss was also observed, but in a lower extent, decreasing from 13.7 to $10.9 \mathrm{cp}$. This could be due to the resistance by the gum formed by the condensation 
products with lignin, which impeded the efficient attack of the bleaching agent. Consequently, the cellulose polymerization degree was preserved but the lignin and hemicellulose contents decreased so little, leading to the generation of a pulp with lower quality than that obtained from P-BSG. Zou et al. (2002) suggested that the hemicellulose presence in the pulp protect the cellulose from degradation by hydroxyl free radicals present during oxygen delignification because hemicellulose compete with the cellulose for these radicals and thus avoid undue loss of molecular weight of the cellulose. This result in less cellulose degradation and the overall viscosity of the pulp is not greatly lowered, but the oxygen delignification is also low.

\section{Conclusions}

Based upon these results it is concluded that the high hemicellulose $(28.4 \% \mathrm{w} / \mathrm{w})$ and extractives $(5.8 \%$ $\mathrm{w} / \mathrm{w})$ contents in the original BSG affected the pulping and bleaching processes. However, soda pulping of acid pretreated BSG gave a cellulose-rich pulp $(90.4 \% \mathrm{w} / \mathrm{w})$ and, although the pulp yield was low $(33.5 \%)$ due to the BSG chemical composition, the pulp properties were good, and therefore it might be used in blends with other pulps or pulped with other raw materials. In addition, such BSG pulp was easily bleached by a chlorine-free sequence using hydrogen peroxide achieving a kappa number of 11.2 , viscosity of $3.1 \mathrm{cp}$, brightness of $71.3 \%$, cellulose content of $95.7 \% \mathrm{w} / \mathrm{w}$ and residual lignin of $3.4 \% \mathrm{w} / \mathrm{w}$. It was thus proved that alkaline and oxidative delignification of acid pretreated BSG is an attractive approach for producing high-purity, chlorine-free, cellulose pulps. This is of considerable interest to modern pulp mills, however, more works need to be done to clarify the bleaching ability, especially on the pulp strength properties.

Considering that this is an initial study on the production of bleached cellulose pulps from BSG, the attained results are of interest and can help further studies on this topic. Nevertheless, it must be detached that the kappa number (11.2) and viscosity $(3.1 \mathrm{cp})$ values obtained for bleached pulp make it unsuitable for the production of good quality paper. Therefore, additional studies on the optimization of bleaching conditions could be useful to establish the conditions able to maximize the pulp bleaching, decreasing the kappa number to a value lower than 11.2 but without cause an extensive reduction in the viscosity.

Acknowledgments This work was supported by Capes (Coordenação de Aperfeiçoamento de Pessoal de Nível Superior), $\mathrm{CNPq}$ (Conselho Nacional de Desenvolvimento Científico e Tecnológico) and FAPESP (Fundação de Amparo à Pesquisa do Estado de São Paulo), Brazil.

\section{References}

Abrantes S, Amaral E, Costa AP, Shatalov AA, Duarte AP (2007) Hydrogen peroxide bleaching of Arundo donax L. kraft-anthraquinone pulp-Effect of a chelating stage. Ind Crop Prod 25:288-293

Argyropoulos DS, Ahvazi BC, Pageau G, Liu Y (1999) Understanding lignin condensation reactions during pulping and oxygen delignification. In: Proceedings of the 6th Brazilian Symposium on the Chemistry of Lignins and Other Wood Components. Guaratinguetá, SP, Brazil, pp 159-166

Baudel HM, Zaror C, Abreu CAM (2005) Improving the value of sugarcane bagasse wastes via integrated chemical production systems: an environmentally friendly approach. Ind Crop Prod 21:309-315

Bianchi ML, Crisol R, Scuchardt U (1999) Bleaching of commercial pulps with $\mathrm{H}_{2} \mathrm{O}_{2}$ catalyzed by heteropolyacids. Bioresour Technol 68:17-21

Brooks RE, Moore SB (2000) Alkaline hydrogen peroxide bleaching of cellulose. Cellulose 7:263-286

Browning BL (1967) Methods of wood chemistry. John Wiley \& Sons, New York

Chen C, Baucher M, Christensen JH, Boerjan W (2001) Biotechnology in trees: towards improved paper pulping by lignin engineering. Euphytica 118:185-195

D’Almeida MLO (1988) Celulose e Papel—Tecnologia de fabricação de pasta celulósica, 2nd edn, vol 1, Senai/IPT, São Paulo, p 559

Fardim P, Durán N (2005) Effects of kraft pulping on the interfacial properties of Eucalyptus pulp fibres. J Braz Chem Soc 16:915-921

Fengel D, Wegener G (1989) Wood. Chemistry, ultrastructure, reactions. Walter de Gruyter, New York

Fortuny A, Font J, Fabregat A (1998) Wet air oxidation of phenol using active carbon as catalyst. Appl Catal BEnviron 19:165-173

Gellerstedt G (2001) The pulping of wood. A chemical challenge. In: Proceedings of the 7th Brazilian Symposium on the Chemistry of Lignins and Other Wood Components. Belo Horizonte, MG, Brazil, pp 79-90

Grace TM, Leopold B, Malcolm EW (1996) Chemical reactions of wood constituents. In: Kocurek MJ (ed) Pulp and paper manufacture: alkaline pulping, vol 5, pp 23-44. The Joint Textbook Committee of the Paper Industry/Tappi/CPPA, Atlanta, GA

Khristova P, Kordsachia O, Khider T (2005) Alkaline pulping with additives of date palm rachis and leaves from Sudan. Bioresour Technol 96:79-85 
Kuhad RC, Singh A (1993) Lignocellulose biotechnology: current and future prospects. Crit Rev Biotechnol 13:151-172

Lapierre L, Berry R, Bouchard J (2003) The effect of magnesium ions and chelants on peroxide bleaching. Holzforschung 57:627-633

Lima DU, Oliveira RC, Buckeridge MS (2003) Seed storage hemicelluloses as wet-end additives in papermaking. Carbohyd Polym 52:367-373

López F, Ariza J, Eugenio ME, Díaz J, Pérez I, Jiménez L (2001) Pulping and bleaching of pulp from olive tree residues. Process Biochem 37:1-7

López F, Díaz MJ, Eugenio ME, Ariza J, Rodríguez A, Jiménez L (2003) Optimization of hydrogen peroxide in totally chlorine free bleaching of cellulose pulp from olive three residues. Bioresour Technol 87:255-261

McMillan JD (1994) Pretreatment of lignocellulosic biomass. In: Himmel ME, Baker JO, Overend RP (eds) Conversion of hemicellulose hydrolyzates to ethanol. American Chemical Society Symposium, Washington, pp 292-324

Mishra VS, Mahajani VV, Joshi JB (1995) Wet air oxidation. Ind Eng Chem Res 34:2-48

Mussatto SI, Roberto IC (2005) Acid hydrolysis and fermentation of brewer's spent grain to produce xylitol. J Sci Food Agric 85:2453-2460

Mussatto SI, Dragone G, Roberto IC (2006a) Brewer's spent grain: generation, characteristics and potential applications. J Cereal Sci 43:1-14

Mussatto SI, Dragone G, Rocha GJM, Roberto IC (2006b) Optimum operating conditions for brewer's spent grain soda pulping. Carbohyd Polym 64:22-28
Rahmawati N, Ohashi Y, Honda Y, Kuwahara M, Fackler K, Messner K, Watanabe $T$ (2005) Pulp bleaching by hydrogen peroxide activated with copper 2,2'-dipyridylamine and 4-aminopyridine complexes. Chem Eng J 112: 167-171

Shatalov AA, Pereira H (2007) Polysaccharide degradation during ozone-based TCF bleaching of non-wood organosolv pulps. Carbohyd Polym 67:275-281

Tanaka R, Wan Rosli WD, Magara K, Ikeda T, Hosoya S (2004) Chlorine-free bleaching of kraft pulp from oil palm empty fruit bunches. JARQ - Jpn Agric Res Q 38: 275-279

Tutus A (2004) Bleaching of rice straw pulps with hydrogen peroxide. Pakistan J Biol Sci 7:1327-1329

Vu THM, Pakkanen H, Alén R (2004) Delignification of bamboo (Bambusa procera acher) part 1. Kraft pulping and the subsequent oxygen delignification to pulp with a low kappa number. Ind Crop Prod 19:49-57

Weinstock IA, Atalla RH, Reiner RS, Moen MA, Hammel KE, Houtman CJ, Hill CL (1996) A new environmentally benign technology and approach to bleaching kraft pulp. Polyoxometalates for selective delignification and waste mineralization. New J Chem 20:269-275

Ye D, Montané D, Farriol X (2005) Preparation and characterization of methylcelluloses from Miscanthus sinensis. Carbohyd Polym 62:258-266

Zou H, Genco JM, van Heiningen A, Cole B, Fort R (2002) Effect of hemicellulose content in kraft brownstock on oxygen delignification. In: Proceedings of the TAPPI Pulping \& Engineering Conference. San Diego, CA, United States 